\title{
Nasjonalt kompetansesenter for aldring og helse
}

\author{
Ved Knut Engedal
}

\begin{abstract}
Nasjonalt kompetansesenter for aldring og helse startet sin virksomhet 1. august 1997, etter et vedtak i Stortingets sosialkomité om at det skulle opprettes et nasjonalt kompetansesenter for aldersdemens. En arbeidsgruppe opprettet av Sosial-og helsedepartementet (slik het det den gang) besluttet at Kompetansesenteret skulle etableres som en delt løsning mellom Psykiatrisk spesialisthelsetjeneste i Vestfold og medisinsk divisjon ved Ullevål universitetssykehus.
\end{abstract}

\section{Oppdraget}

Senteret fikk tildelt fire oppgaver:

1) Drive forsknings- og utviklingsarbeid for å bedre behandlingsog omsorgstilbud til personer med demens og deres pårørende.

2) Tilby rådgivning og veiledning til til kommune- og spesialisthelsetjenesten.

3) Utvikle Iæremateriell.

4) Tilby undervisning om aldersdemens.

I 1999 fikk Kompetansesenteret tildelt nye oppgaver i fagfeltet Funksjonshemning og aldring (FoA), og i 2003 om Utviklingshemning og aldring (UA). Begge de nye oppgavene startet som 3-årige prøveprosjekter, men ble varige tiltak etter prøveperioden. I tillegg har Kompetansesenteret siden 1997 drevet kompetansehevende arbeid innen fagfeltet alderspsykiatri, men har ikke status som et kompetansesenter i alderspsykiatri. Dette er det søkt om, og ifølge offentlige kilder er det foreslått at Kompetansesenteret skal drive slik virksomhet. Vi venter på finasiering.

\section{Organisering og ansatte}

På grunn av dreining av oppgavene innenfor fagfeltet demens til også å omfatte aldringsfenomen og sykdom blant andre svake grupper, skiftet Kompetansesenteret navn i 2007 til Nasjonalt kompetansesenter for aldring og helse (NKAH). Helse- og omsorgsdepartementet god- kjente navneskiftet. Oppgavene er de samme som før, men de siste to årene har NKAH også arrangert kurs for helsepersonell i fagområdet geriatri. Per 2011 er 55 personer ansatt ved senteret, tilsvarende 45 årsverk. Halvparten av de ansatte er fasttilsatte fagpersoner fra mange fagområder, som psykiatri, geriatri, psykologi, pedagogikk, etnografi, fysioterapi, vernepleie og journalistikk. Ulike yrkesgrupper er representert, som leger (psykiatri), psykologer, sykepleiere, ergoterapeuter, bibliotekarer, lærere, vernepleiere, journalister og merkantilt personell. Den andre halvparten er prosjektansatte som enten arbeider i utviklingsprosjekter eller forskningsprosjekter av ett til fire års varighet. Per 2011 har kompetansesenteret to professorer, en førsteamanuensis, fire postdoktorer, to seniorforskere og åtte ph.d.-stipendiater.

\section{Forskning og utviklingsprosjekter}

All forskning som utføres kan betegnes som praktisk klinisk forskning. Eksempler på tidligere og nåværende forskning er: om psykisk sykelighet blant sykehjemspasienter og hjemmesykepleieklienter, spesielt depresjon; om bruk av tvang og makt i eldreomsorgen; om legemiddelbruk; om byrde til pårørende til personer med demens; om miljøbehandling i sykehjem; livsløpshistorier. Det utføres både observasjonsstudier og kontrollerte ikkemedikamentelle intervensjonsstudier. Både kvantitative og kvalitative metoder tas i bruk i de ulike studiene. Utviklingsprosjekter kan handle om kartlegging og tilrettelegging av nye tjenester for eldre med ulike handikap, som demens, utviklingshemning, redusert syn og hørsel, poliomyelitt og så videre.

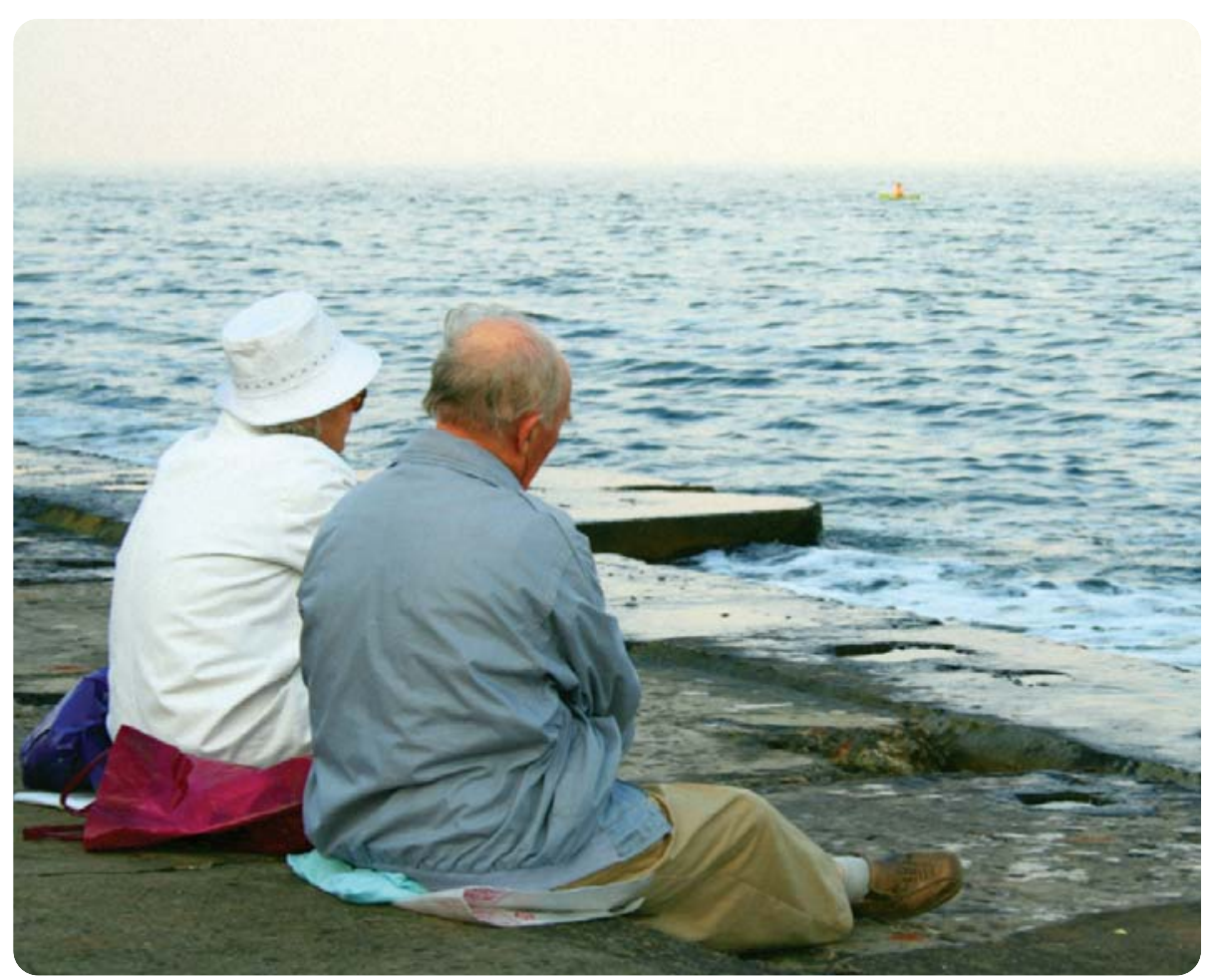


Det er vanlig å knytte mastergradsoppgaver til utviklingsprosjektene, noe som har ført til at svært mange av prosjekttilsatte med 3-årig høgskoleutdanning nå har fătt mastergrad, eller er i gang med mastergradsutdanning. Mange av utviklingsprosjektene utføres på oppdrag av Helsedirektoratet, eller andre offentlige organ. Årlig publiserer NKAHs ansatte om lag 15 fagfellevurderte vitenskapelige artikler.

\section{Undervisning}

Undervisning om eldres helse opptar en stor del av senterets virksomhet, og undervisningen rettes primært mot kommunalt helsepersonell, men i noen grad også mot personell i spesialisthelsetjenesten. Undervisningen tilbys i form av kurs og konferanser (ca. 25 per år, med rundt regnet 300 deltagere hvert år), men i $\varnothing$ kende grad tas e-læringsmetoder i bruk. En annen undervsiningsmetode som er tatt i bruk, er studiegrupper på arbeidsplassene. "Eldreomsorgens $\mathrm{ABC}$ og Demensomsorgens $\mathrm{ABC}$ " er en stor suksess - per dags dato er 9000 personer på kurs i studiegrupper på egen arbeidsplass. Disse bedriftsinterne opplæringstiltakene går over flere år, og deltagerne blir kreditert opplæringen i henhold til faglige videreutdanningsl $\varnothing \mathrm{p}$. Kompetansesenteret har dessuten status som fagskole, godkjent av NOKUT (Nasjonalt organ for kvalitet i utdanningen) i fagområdene demens og alderspsykiatri og driver et 1-årig studietilbud. Videoundervisning og nettbasert undervisning er de bærende undervisningsformene i fagskolen.

\section{Læremateriell}

Undervisningsmateriell som benyttes i det kompetansehevende arbeidet produseres for den st $\varnothing$ rste delen av kompetansesenterets ansatte. Senteret har et eget forlag, Aldring og Helse. Forlaget utgir 5-10 nye bøker og annet læremateriell hvert år, og utgir dessuten tidsskriftet Demens og alderspsykiatri fire ganger i året. Undervisningsfilmer og lydbøker produseres også.

\section{Nettverk}

Kompetansesenteret har opparbeidet seg et bredt nasjonalt og internasjonalt nettverk, spesielt i fagområdet alderspsykiatri. I handlingsplanen for norsk alderspsykiatri 2001-2010 og i den reviderte planen for 2011-2020, er Nasjonalt kompetansesenter for aldring og helse fremhevet som en viktig samarbeidspartner i norsk alderspsykiatri og som en organisasjon som man forventer skal ta initiativ til forsknings- og utviklingsarbeid. Kompetansesenteret har fulgt opp dette, og arrangerer forskningsdager og tverrfaglige alderspsykiatrikonferanser, og er en aktiv initiativtaker, medspiller og veileder til alderspsykiatrisk forskning ved flere sykehus. Som gjenytelse deltar ansatte ved alderspsykiatriske avdelinger rundt om i landet som undervisere ved kompetansesenterets kurser og konferanser.

Internasjonalt har NKAH nær og regelmessig kontakt med lignende sentra i Danmark og Sverige, og er dessuten initiativtaker til et europeisk nettverk for kompetansesentra om demens.
Disse nettverkene har årlige samarbeidsmøter. Ansatte ved NKAH er dessuten aktive ved ulike internasjonale kongresser.

\section{Aktiviteter som kan knyttes opp mot selvmordsproblematikk for eldre?}

Kompetansesenteret har ingen forskningsaktivitet eller klinisk aktivitet knyttet opp mot selvmordsproblematikk. I det arbeidet som gjøres innefor fagområdet alderspsykiatri, som ikke er finansiert, tangerer selvmordsproblematikk forskning om depresjon hos eldre. Problematikken tas også regelmessig opp på kurs og konferanser i alderspsykiatri. Den dagen kompetansesenteret får status og tildeles midler som et kompetansesenter i alderspsykiatri, vil det være naturlig å $\varnothing$ ke arbeidet med selvmordforebygging.

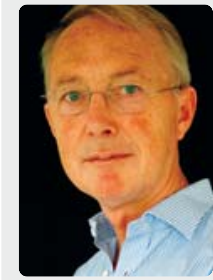

Knut Engedal er professor i alderspsykiatri ved Universitetet i Oslo og fag- og forskningssjef ved Nasjonalt kompetansesenter for aldring og helse. Han har bl.a. skrevet bøkene Aldersdemens - Fakta og

utfordringer (5. utgave 2009) og Urunde hjul. Alderspsykiatri i praksis (2. utgave 2007).

Mer informasjon om om ulike prosjekter, undervisning, nettverk, etc. ved Nasjonalt kompetansesenter for aldring og helse se: www.aldringoghelse.no

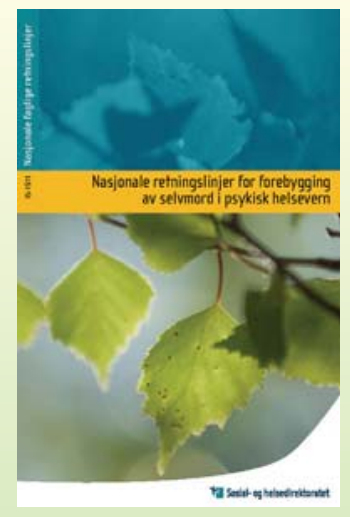

\section{Helsetilsynet mener de nasjonale retningslinjene for forebygging av selvmord er implementert}

Det er nevnt i Medisinalmelding 2010 (s. 51) der tilsynet med håndtering av selvmordstruede pasienter i distriktspsykiatriske døgnenheter er omtalt.

Tilsynet hadde som formål å undersøke om og hvordan helseforetaket gjennom sin styring og ledelse etterlever krav i lover og forskrift om forsvarlig virksomhet. Tilsynet omfattet vurderingen av fasene i et pasientbehandlingsforl $\varnothing \mathrm{p}$.

Det ble ikke funnet avvik ved disse tilsynene. 